\title{
Climate sensitivity of radial growth in Norway spruce (Picea abies (L.) Karst.) under different $\mathrm{CO}_{2}$ concentrations
}

\author{
Aysan Badraghi ${ }^{1{ }^{*}}$, Radek Pokorný ${ }^{1,2}$, Kateřina Novosadová ${ }^{1,2}$, \\ Justina Pietras $^{1,2}$ and Michal V. Marek ${ }^{1}$
}

\begin{abstract}
Badraghi, A., Pokorný, R., Novosadová, K., Pietras, J., Marek, M.V. 2016. Climate sensitivity of radial growth in Norway spruce (Picea abies (L.) Karst.) under different $\mathrm{CO}_{2}$ concentrations. - Forestry Studies | Metsanduslikud Uurimused 64, 43-56. ISSN 1406-9954. Journal homepage: http://mi.emu.ee/forestry.studies
\end{abstract}

\begin{abstract}
This investigation examined the effects of two different carbon dioxide concentrations $\left(\left[\mathrm{CO}_{2}\right]\right)$ : Ambient $\left(\mathrm{A}, 385 \mu \mathrm{mol}\left(\mathrm{CO}_{2}\right) \mathrm{mol}^{-1}\right)$ and elevated $\left(\mathrm{E}, \mathrm{A}+385 \mu \mathrm{mol}\left(\mathrm{CO}_{2}\right) \mathrm{mol}^{-1}\right)$ ) on the tree-ring width and early to latewood proportion in Norway spruce for seven years (2006-2012). Further, to improve our understanding of the influence of climatic variables, we assessed the effects of precipitation and temperature. Our observations showed that spruce trees growing under elevated $\mathrm{CO}_{2}(\mathrm{EC})$ formed less early $(p>0.05)$ and latewood $(p$ $<0.05)$ and hence smaller annual increments $(p>0.05)$ than trees in ambient $\mathrm{CO}_{2}(\mathrm{AC})$. Early to latewood proportion was nearly $73 \%$ and $75 \%$ in AC and EC, respectively. In both $\mathrm{CO}_{2}$ concentrations, the largest tree-rings and earlywood width was observed during 2009 and 2010, which is coincident with the highest precipitation in May (2010) and the highest air temperature in April (2009). Moreover, to determine the association between the latewood formation and air temperature during the second half of the growing season, and correlation between the earlywood formation and precipitation during the first half of the growing season we run Spearman's correlation test, the determination coefficient values for latewood formation were $r=0.45$ (AC) and $r=0.68$ (EC), and for earlywood formation were $r=0.53$ (AC) and $r=0.42$ (EC), although coefficient values were not statistically significant $(p>0.05)$. Also, our study indicated that temperature had stonger influence than precipitation in EC, but in AC precipitation had the strongest effect on radial growth.
\end{abstract}

Key words: ambient $\mathrm{CO}_{2}$, elevated $\mathrm{CO}_{2}$, wood formation, radial increment, carbon relations, conifers.

Authors' addresses: ${ }^{1}$ Department of Biomass and Water Regime, Global Change Research Centre, Academy of Science of the Czech Republic, Belidla 986/4a, CZ 60300 Brno, Czech Republic; ${ }^{2}$ Department of Silviculture, Faculty of Forestry and Wood Technology, Mendel University in Brno, Czech Republic; *e-mail: aysan.badraghi@yahoo.com

\section{Introduction}

The extension of the greenhouse-gas record shows that present day levels of $\mathrm{CO}_{2}$ are unprecedented during the past 420,000 years (Petit et al., 1999; Pearson \& Palmer, 2000; Augustin et al., 2004). Direct measurements of $\mathrm{CO}_{2}$ in the atmosphere and in air trapped in ice showed that atmospheric $\mathrm{CO}_{2}$ increased by about 40\% from 1800 to 2012 (IPCC, 2013; Wolff et al., 2014).The effects of this change on plants will be wide-ranging
(Crookshanks et al.,1998; Smith et al., 2013; Madhu \& Hatfield, 2013).Woody perennials, particularly forest species, play a significant part in the global carbon cycle; they occupy about $30 \%$ of land surface, $70 \%$ of the land biomass, and carry out $60 \%$ of the total photosynthesis (Egli \& Körner, 1997). These factors, combined with trees long life spans, provide them with the potential to be considerable sinks for the long term storage of carbon (Agrawal \& Agrawal, 1999; Mustafa, 2012). Several papers have reported that 
elevated $\mathrm{CO}_{2}$ enhances growth (LaMarche et al., 1984; Crookshanks et al., 1998; Jarvis, 1998; Jach \& Ceulemans, 1999; Kilpeläinen et al., 2005, 2007; Pokorný et al., 2013), especially when sufficient nutrients are supplied (Brown \& Higginbotham, 1986; Atwell et al., 2002; Yazaki et al., 2005; Drake et al., 2011). Also, Nicolussi et al. (1995) studied this effect on subalpine Swiss pine Pinus cembra L. and they found a steady and significant increase of mean ring width. Contrariwise, some researchers (such as Hättenschwiler et al., 1996; Yazaki et al., 2001; Temperton et al., 2003; Norby \& Zak, 2011; Pokorný et al., 2012a; Bader et al., 2013; Klein et al., 2016) reported that tree growth rate was not simulated by elevated $\left[\mathrm{CO}_{2}\right]$. Makino \& Mae (1999) reported that long-term $\mathrm{CO}_{2}$ enrichment accumulation of carbohydrates in leaves and may lead to the repression of photosynthetic gene expression and excess starch seems to hinder $\mathrm{CO}_{2}$ diffusion.

Tree growth is strongly influenced, among other factors, by climate. Much knowledge regarding climate-growth relationships has been gained by studying tree rings (Buentgen et al., 2006; Underwood, 2007; Shishkova \& Panayotov, 2013; Rohner et al., 2016). Radial growth variability of Norway spruce (Picea abies (L.) Karst.) in association with climatic variables has been documented in several studies from different geographical regions. In southeastern Finland, Norway spruce ring width was strongly affected by July temperature and total precipitation in August (ZubizarretaGerendiain et al., 2012). Whilst, Wimmer \& Grabner (1997) found that above-normal precipitation from June to August decreased tree-ring width in eastern Germany. Favourable factors in the Swiss lowlands were high precipitation between MarchJune and low precipitation between JulySeptember (Rohner et al., 2016), and it was high precipitation between June-July in southern Norway (Selås et al., 2002). In the Polish part of the Baltic sea-coast, growth was affected by precipitation and temperature during the growing season (Feliksik \&
Wilczynski, 2009), but at the north-eastern part of this country (Poland) showed negative responds to temperature in June, and the most favourable growth conditions were wet and mild summers (Bijak, 2009). In eastern Romania, at high elevations ( $\geq$ $1300 \mathrm{~m}$ a.s.1.) temperatures in June and July have a positive influence on tree-ring width and latewood formation, whereas at lower elevations ( $\leq 1000 \mathrm{~m}$ a.s.1.) the warm temperatures from June and July determine a reduced tree-ring width, in low elevation tree-ring width controlled mainly by summer precipitations (Sidor et al., 2015). Also, in Germany (in the Bavarian Forest) Wilson \& Hopfmueller (2001) found same results for high elevations ( $\geq 1070 \mathrm{~m}$ a.s.l.) and low elevations ( $\leq 680 \mathrm{~m}$ a.s.1.). But in the highland region of the Czech Republic longitude, latitude and altitude of the original locations of the provenances affected significantly, and average annual temperature and average annual precipitation were not significant (Ulbrichová et al., 2015). Helama et al. (2016) compared the growth variability of this species under various site conditions in Estonia. They reported that western chronologies correlated positively and significantly with early-summer (June) precipitation, while eastern chronologies showed positive and significant correlation with mid-winter (January) precipitation.

Earlywood trends during the past 100 years were closely associated with changes in May rainfall patterns (Wimmer et al., 2000), and the proportion of latewood increased with low precipitation in the growing season (Kennedy, 1961). Furthermore, late spring and entire growing season temperature influence the formation of light rings (rings that are light-colored due to incomplete latewood cell wall development) formation in black spruce at the tree line near bush lake, northern Québec (Yamaguchi et al., 1993). Pokorný et al. (2012b) found that ample water supply during spring time in Beskydy Mts. (Czech Republic) supports earlywood formation in Norway spruce. Also, Lebourgeois (2000) re- 
ported that warm May temperatures could reduce earlywood width of Corsican pine from western France, by creating drought stress conditions at the beginning of the growing season. As a consequence of dry conditions, coniferous trees may produce radially smaller diameter tracheids within their rings before regular latewood formation starts. Shishkova \& Panayotov (2013) found positive significant correlations between precipitation in early summer and Black pine (Pinus nigra Arnold) radial growth in Slavyanka Mts. in Bulgaria. In the Krkonose Mountains in the Czech Republic cold summers are the cause of small radial increments in the old growth spruce forests near the upper tree line (Sander et al., 1995), whilst elevated air temperature during summer time in highland region of this country stimulates latewood growth in Norway spruce (Pokorný et al., 2012b). Campelo et al. (2006) reported no significant positive relationship between precipitation in August and latewood formation in Stone pine Pinus pinea L. from a dry Mediterranean area in southern Portugal.

To simulate the long-term effects of elevated $\mathrm{CO}_{2}$ on Norway spruce radial growth, Norway spruce seedlings grew inside two glass domes under ambient (385 ppm) and elevated (700 ppm) $\mathrm{CO}_{2}$, for seven years. Our objectives were: (1) compare tree-ring (early and latewood) width and early to latewood proportion changes in different atmospheric $\left[\mathrm{CO}_{2}\right]$; (2) evaluate the association among earlywood formation and precipitation in the first half of the growing season; (3) evaluate the association among latewood formation and air temperature in second half of the growing season. We hypothesized that spruce seedling would respond to elevated $\mathrm{CO}_{2}$ by: (1) by producing wider tree-rings, (2) produce wider earlywood, because depending on the authors's observations, in this research root biomass allocation in EC (elevated $\mathrm{CO}_{2}$ ) was higher than $\mathrm{AC}\left(\right.$ ambient $\left.\mathrm{CO}_{2}\right)(p>0.05)$, therefore, we expected enhancement of root biomass allocation would support earlywood by in- creasing water use efficiency. (3) produce wider latewood, due to reduced transpiration of EC plants, temperature of these plants will be increased hence we supposed that higher temperature support latewood.

\section{Material and Methods}

\section{Area descriptions}

The study site $\left(49^{\circ} 30^{\prime} \mathrm{N}\right.$ and $18^{\circ} 32^{\prime} \mathrm{E}, 908$ $\mathrm{m}$ a.s.1.) was in the Bílý Kř́žz (i.e., Beskydy Mts.) which is situated in the eastern part of Czech Republic in bordering with Slovakia.). Mean annual air temperature and precipitation were $6.5^{\circ} \mathrm{C}$ and $1330 \mathrm{~mm}$, respectively. The soil type in the upper soil horizons is ferric podzol, the geological bedrock is formed by Mesozoic Godula sandstone (flysh type). In autumn 2005, threeyear-old Norway spruce and two-year-old European beech (Fagus sylvatica L.) seedlings were cultivated under two different atmospheric $\mathrm{CO}_{2}$ concentrations: ambient (385 $\left.\mu \mathrm{mol}\left(\mathrm{CO}_{2}\right) \mathrm{mol}^{-1}\right)$, and elevated (ambient $\left.+385 \mu \mathrm{mol}\left(\mathrm{CO}_{2}\right) \mathrm{mol}^{-1}\right)$, inside two glass domes. At the time of planting, the mean height of beech and spruce seedlings were $77.1 \pm 14.6 \mathrm{~cm}$ and $46 \pm 7.0 \mathrm{~cm}$, respectively. Inside each glass dome 96 trees (spruce and beech) were planted in triangular spacing. In each location in one dome, size and species of trees were comparable with pairedlocation in another glass dome.

The shape of glass domes was open-top square with $9 \quad 9 \mathrm{~m}$ in length and $7 \mathrm{~m}$ heigh in the central part. The dome construction was based on a massive iron frame with 72 adjustable windows which anchored on a concrete base (Figure 1). Soils inside the glass domes were natural soils from the study zone and soil communication between inner and outer space controlled by penetration tubes, which were placed in concrete base. More detailed description about the glass dome infrastructure can be found in Urban et al. (2001). The air with ambient and elevated $\left[\mathrm{CO}_{2}\right]$ was diffused by using four radial fans and two auxiliary 


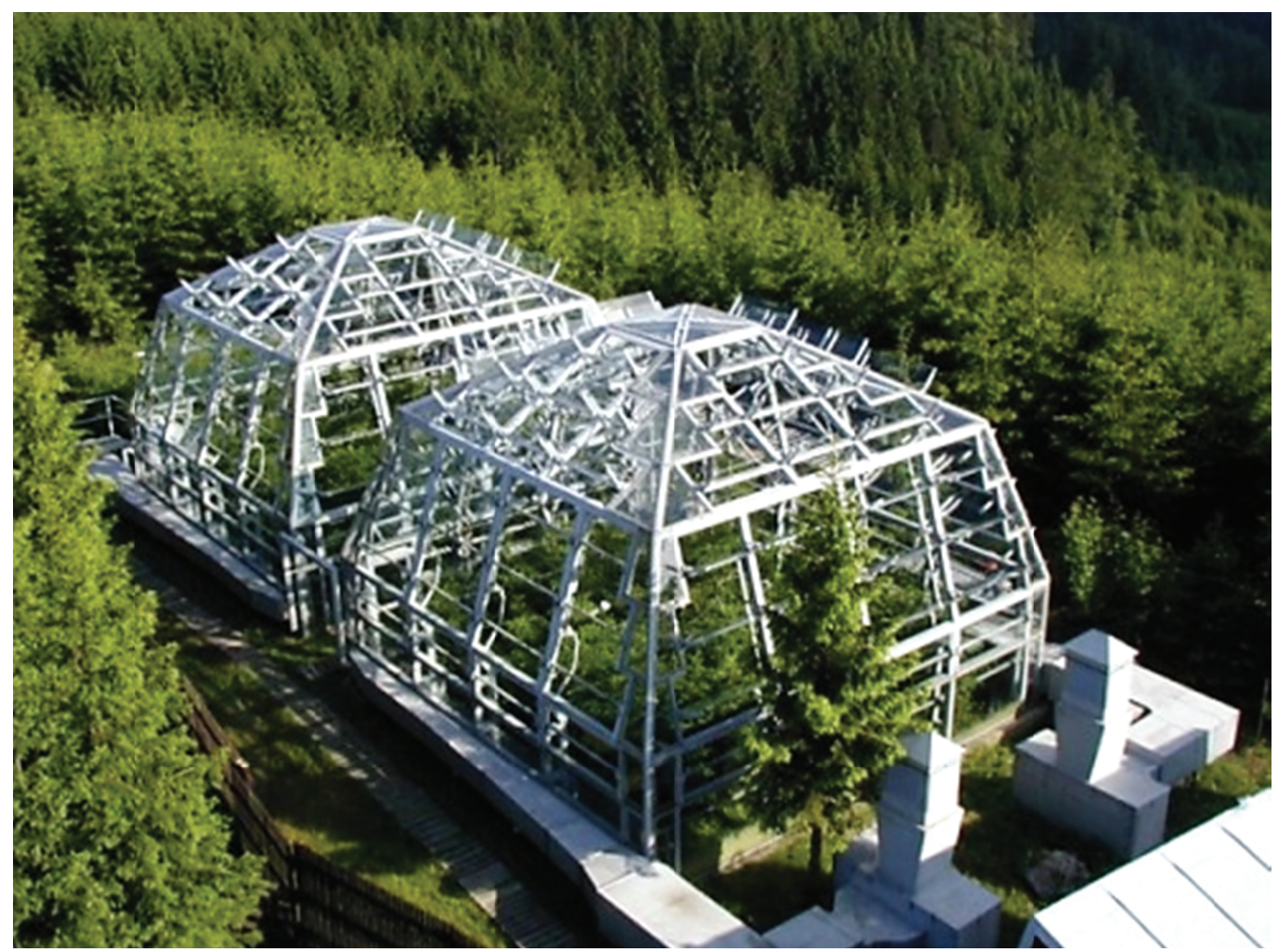

Figure 1. Photograph of glass domes at the research site.

fans (models RNH 400 and 500 W, Janka, Czech Republic). The $\mathrm{CO}_{2}$ fumigation started in spring 2006 which fumigated everyday 24 hours (April-November).

\section{Sampling and width estimation}

All trees were cut down during summer 2013, and radial growth was assessed from 2006 to 2012 (due to incomplete tree-rings during 2013). By using a chainsaw, a $5 \mathrm{~cm}$ long stem segment (30-35 cm above the stem base) was removed from each felled tree. These stem discs were oven-dried at $80 \pm 5^{\circ} \mathrm{C}$ for 48 hours and two hours at 105 $\pm 3{ }^{\circ} \mathrm{C}$. To improve visualization of treerings, early- and latewood boundaries, transverse sections of all removed discs at the upper base were sanded until the treerings, earlywood and latewood boundaries were clearly visible. Subsequently, cross section images were taken at 600 DPI reso- lution and saved in JPEG format using a scanner (CanoScanLiDe 1100, Canon Inc., Japan). Growth layers, early- and latewood width series were measured in four pre-defined directions by using an image analysis program (ACC, Sofo Brno, Czech Republic), and the mean of four radii was used as the individual tree-ring width.

\section{Climate data}

Climate variables were calculated based on monthly sums of precipitation $(\mathrm{mm}$, Automatic Precipitation Gauge 386C, MetOne Instrument, USA) and monthly air temperature means $\left({ }^{\circ} \mathrm{C}\right.$, Sensor RHA1, Delta-T Devices, UK). Air temperature and precipitation data collected from meteorological station situated next to the glass domes. Microclimate parameters such as air temperature and humidity gradients inside domes maintained at similar levels 
to natural conditions (for more than $80 \%$ of the time). To apply correlation analysis, mean air temperature, precipitation sums, precipitation in growing season (May-October), air temperature in growing season, precipitation in first half of growing season (May-July), precipitation in second half of growing season (August-October), temperature in first half of growing season and temperature in second half of growing season were calculated, for every year.

\section{Statistical analysis}

All statistical analyses were performed by the Statistica software (Statistica 12, StatSoft, Inc.), before analysis of data normality was tested and it approximately follow a normal distribution. A paired sample $t$ test was employed to compare the means of studied parameters (tree-ring, early and latewood width) between AC and EC, and inter-year difference was tested by analysis of variance (ANOVA). Following ANOVA, Scheffe's post hoc test for significant betwee-group differences. To reach study goals, association between precipitation in the first half of the growing season and earlywood formation and between temperature in the second half of the growing season and latewood formation were tested using the nonparametric (distribution-free) Spearman's rank correlation coefficient. Spearman's correlation is a parameter to be estimated quantifying strength of a relationship and so resembles Pearson. It assesses how an arbitrary monotonic function can describe the relationship between two variables, without making any assumptions about the frequency distribution of the variables (Hauke \& Kossowski, 2011). We also tested associations between studied parameter with variables such as precipitation in May, air temperature in April, annual sums precipitation, precipitation in the second half of the growing season, mean annual air temperature, precipitation in the growing season, air temperature in the growing season and the first half of the growing season.

\section{Results}

$\left[\mathrm{CO}_{2}\right]$ and tree-ring width relationships Our results did not support our hypotheses of greater early and late wood formation or overall annual increment under EC compared to AC. Norway spruce seedlings growing under EC had lower mean treering (Figure 2a), early- (Figure 2b) and latewood ( $p<0.05$, Figure 2c) width compared to AC. Only during 2009 tree-ring width, and during 2008 and 2009 earlywood width in EC was higher than AC. There were no statistically significant differences neither in annual radial increment nor earlywood production (Figure 2a and 2b). In contrast, we found statistically significant differences for latewood during 2007 ( $p=0.008), 2008$ ( $p=$ $0.02)$ and $2011(p=0.04)$ between EC and AC (Figure 2c).

In both $\left[\mathrm{CO}_{2}\right]$, the largest latewood widths were observed during 2011. The largest tree-rings and earlywood widths were observed during 2009 and 2010, and the smallest width was observed during 2006 and 2007 which could be due to a transplanting shock from the nursery to the glass dome. During 2010, the largest tree-rings and earlywood width occurred in the AC treatment, but during 2009, the highest observation was in the EC. In AC, significant inter-year differences observed between 2010-2006 and 2010-2007 for earlywood and tree-ring, and between 2006-2009 and 2006-2010 for latewood. In EC, significant inter-year differences detected between 2009-2006 and 2009-2007 for earlywood and tree-ring, and between 2006-2009 and 2006-2010 for latewood (Figure 3).

\section{Early to latewood proportion}

Earlywood width series was nearly $73 \%$ and $75 \%$ of the total tree-ring width in AC and EC, respectively, indicating earlywood growth dominates final ring width under the stated environmental conditions in juvenile $P$. abies. In the both $\left[\mathrm{CO}_{2}\right]$, the greatest early to latewood proportion was observed during 2009 and 2010. In contrast, higher 

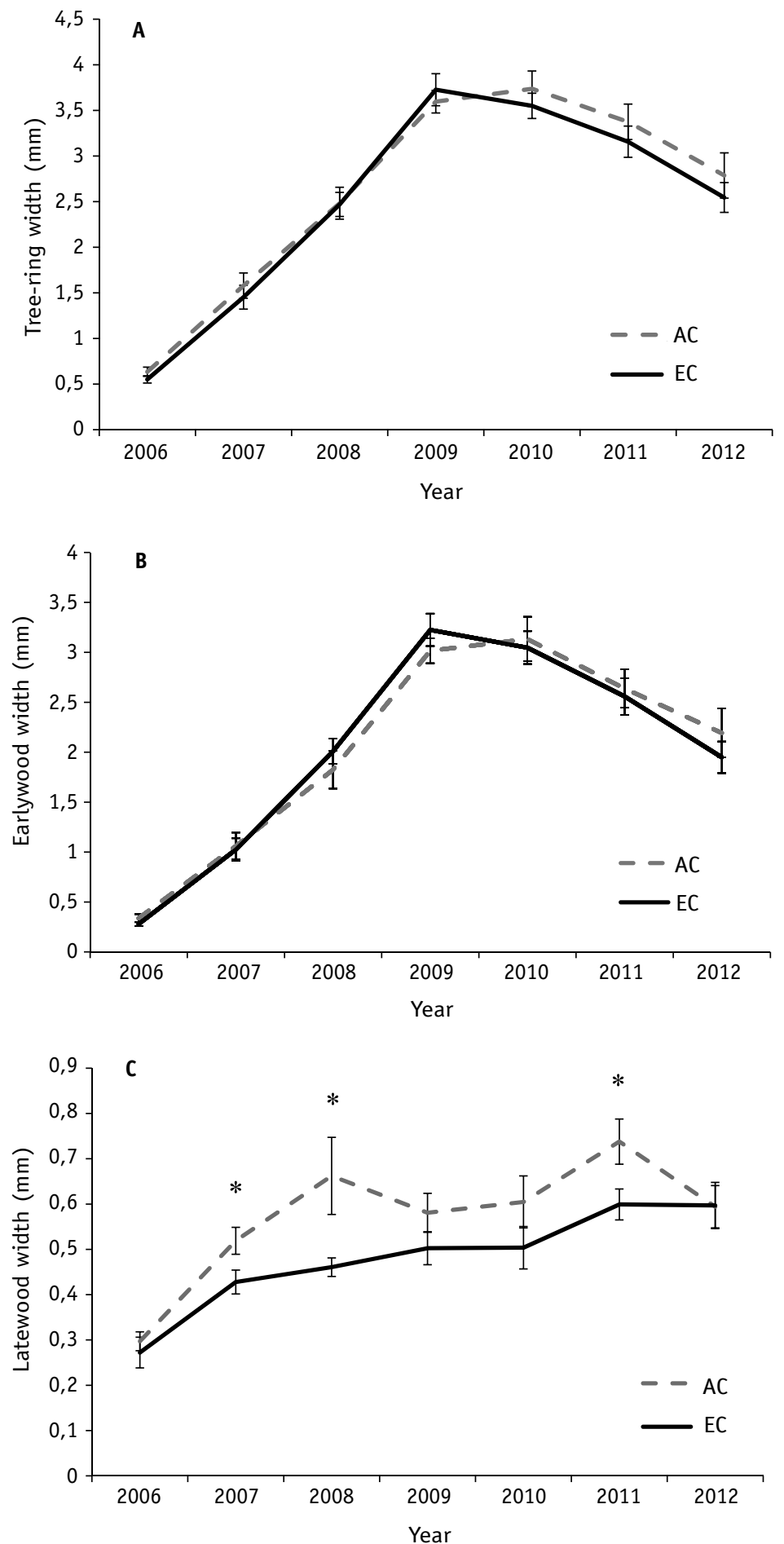

Figure 2. Mean annual tree-ring, early and latewood increment in the $\mathrm{EC}$ (elevated $\mathrm{CO}_{2}$ ) and $\mathrm{AC}$ (ambient $\left.\mathrm{CO}_{2}\right)(2006-2012)$.

Means \pm standard error, $\mathrm{n}=22,{ }^{*} p<0.05$. 

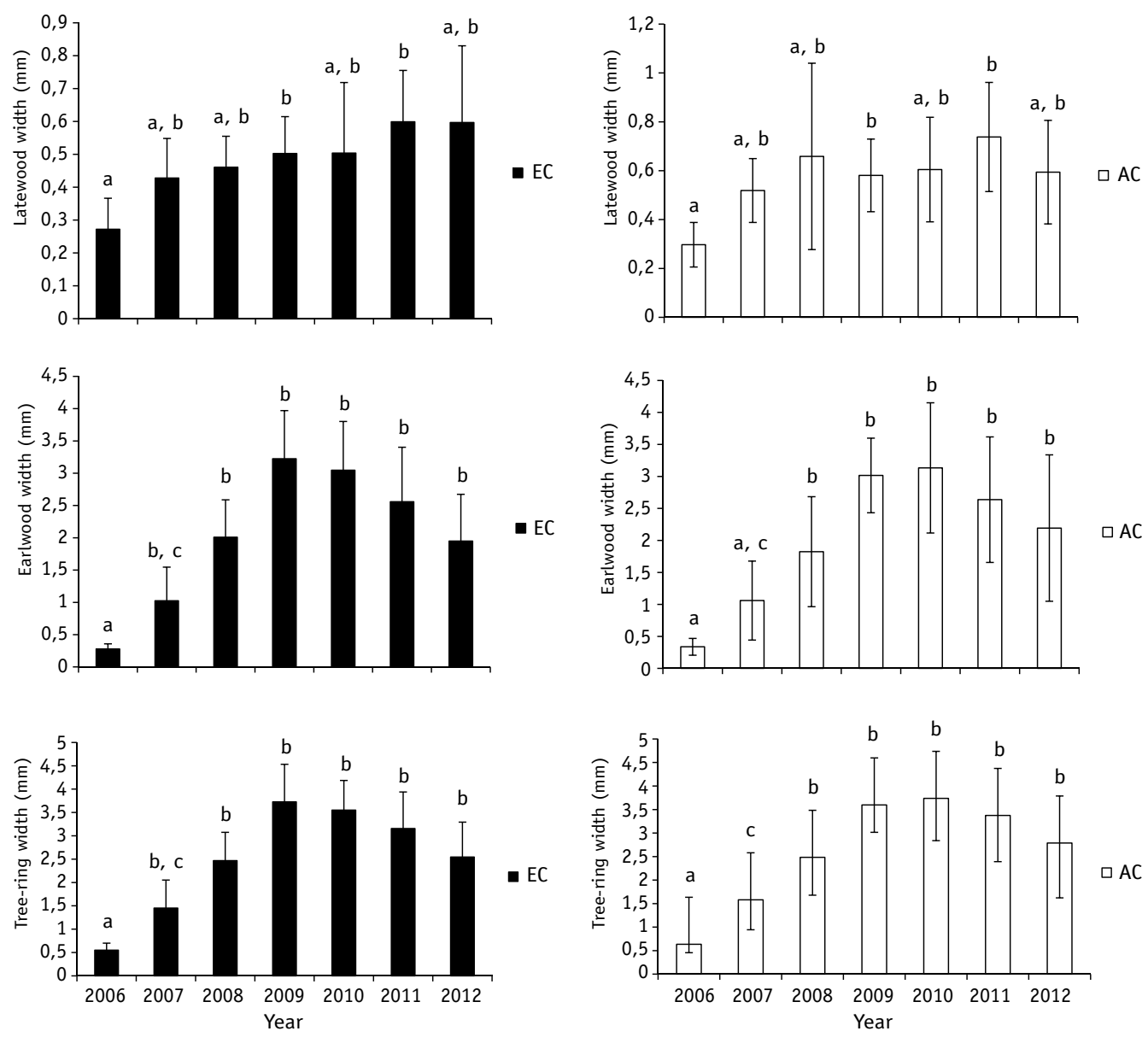

Figure 3. Mean annual tree-ring, early- and latewood increment inside the each dome (2006-2012), statistically significant inter-year differences years are symbolized by stars mark. Different lowercase letters indicate statistically significant differences inter-year. $\mathrm{EC}$ - elevated $\mathrm{CO}_{2}, \mathrm{AC}-$ ambient $\mathrm{CO}_{2}$.

proportion of latewood to earlywood was observed during the first two years of the experiment (2006 and 2007).

\section{Climate-tree ring relationship}

In 2010, the majority of the precipitation fell in the first half of the growing season with May being the wettest month (394 mm; Table 1). The highest amount of annual precipitation occurred during 2007 most of which fell during the non growing season, ruling it out as a key factor. Furthermore, the driest year was 2011, which is coincident with the largest latewood width in both $\left[\mathrm{CO}_{2}\right]$. Probably, latewood formation was not sensitive to the range of precipitation in second half of the growing season.

Air temperature ranges for each month, year and (the second half of) the growing season are shown in Table 2. 2011 had the highest temperature in the second half the growing season and annual temperature, and 2012 had the highest temperature in the growing season. April temperatures had the strongest influence on tree growth (Table 3). April temperature during 2007, 2009, 2010 

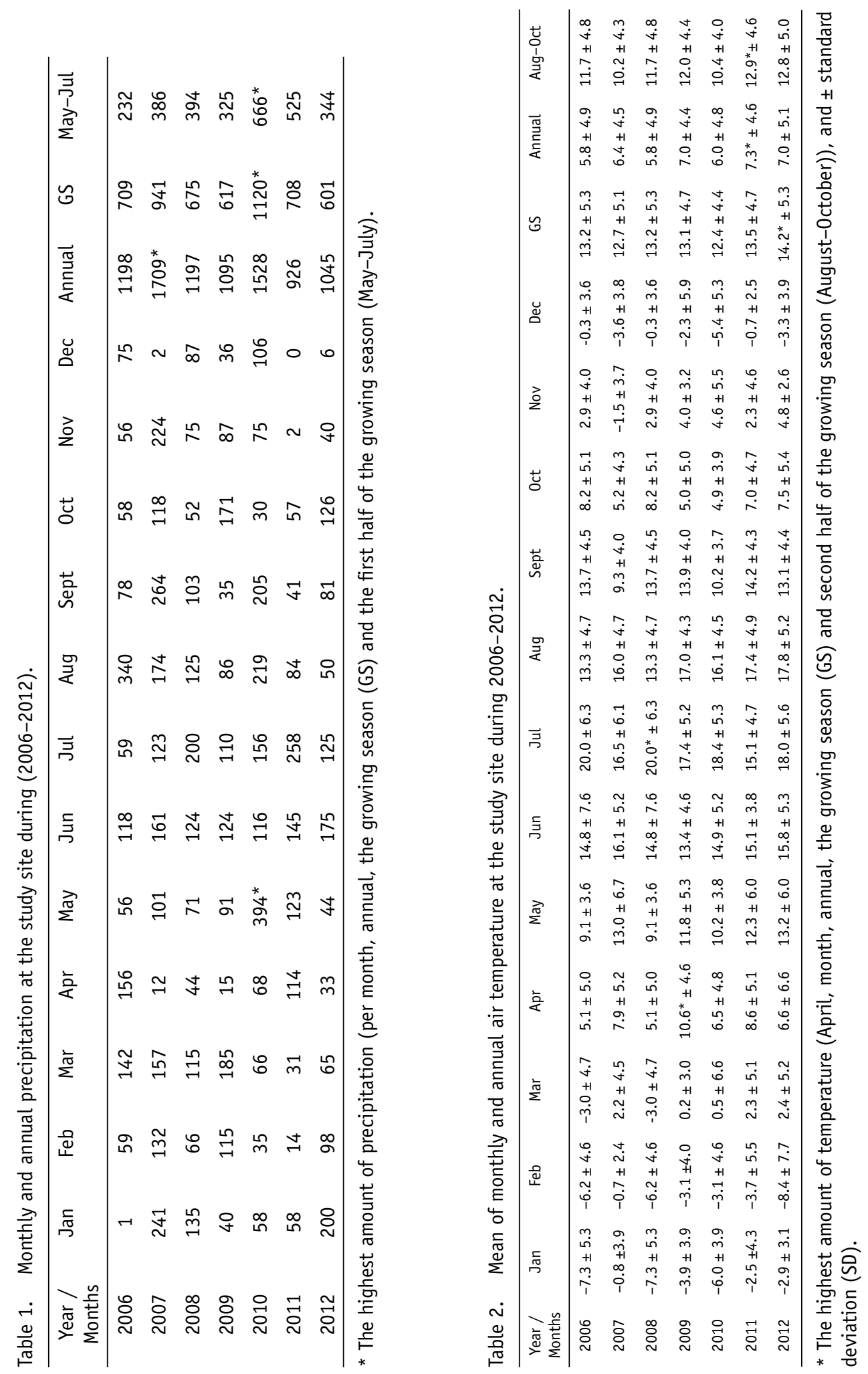
and 2011 was above $0^{\circ} \mathrm{C}$ and mean daily air temperature ranged from 0.4 to $15^{\circ} \mathrm{C} ; 6$ to $14^{\circ} \mathrm{C} ; 1$ to $15^{\circ} \mathrm{C}$ and from 1 to $14^{\circ} \mathrm{C}$ in 2007 , 2009, 2010 and 2011, respectively. Further, the lowest daily temperature-frequency was observed only during April 2009. (Figure 4).

In EC, significant positive correlations were found between tree-ring and air temperature in April $(r=0.83)$ and between latewood and annual air temperature $(r=$ 0.79 ). Significant negative correlation was between latewood and precipitation in the second half the growing season $(r=$ -0.82). In AC, significant positive correlation was observed between latewood and precipitation in the growing season $(r=$ 0.79 ) and significant negative correlation was between latewood and precipitation in the second half the growing season $(r=$ $-0.79)$. In both $\left[\mathrm{CO}_{2}\right]$, correlations between radial increments and the growing season temperature were small, and only latewood has shown positive response to this factor. However annual sums of precipitation were negatively correlated with radial growth. The highest positive correlation coefficients were observed between April temperature and radial increments. Association among precipitation in the first half of the growing season and earlywood formation was moderately positive in $\mathrm{AC}(r=0.53)$ and $\mathrm{EC}(r=$ 42). Association between temperature in the second half of the growing season and latewood formation was strongly positive in EC $(r=0.68)$ and moderately positive in AC $(r=0.45)$, coefficient values were not statistically significan (Table 3 ).

\section{Discussion}

The first two papers reported no statistically significant growth differences between ambient and elevated $\mathrm{CO} 2$ but did not report diminished radial growth under elevated $\mathrm{CO}_{2}$.

Generally, the prolonged exposure to $\mathrm{CO}_{2}$ enrichment reduces the initial stimulation of photosynthesis in many species, and suppresses photosynthesis (Makino \& Mae, 1999). Also, our observation indicated that radial growth was diminished by increasing

Table 3. Results of Spearman's test (MP - precipitation in May, ApT - air temperature in April, AP - annual sums precipitation, AT - mean annual air temperature, GSP - precipitation in the growing season, GST - air temperature in the growing season, PFHG - precipitation in the first half of the growing season, TFHG - temperature in the first half the growing season, PSHG - precipitation in the second half of the growing season, TSHG - temperature the second half of the growing season). $\mathrm{TR}$ - tree-ring increments, $\mathrm{EW}$ - earlywood formation, $\mathrm{LW}$ - latewood formation, $\mathrm{AC}$ - ambient $\mathrm{CO}_{2}$, $\mathrm{EC}$ - elevated $\mathrm{CO}_{2}$.

\begin{tabular}{ccccccccccc}
\hline $\begin{array}{c}\text { Studied } \\
\text { parameters }\end{array}$ & MP & ApT & AP & AT & GSP & GST & PFHG & TFHG & PSHG & TSHG \\
\hline TR-AC & 0.57 & 0.72 & -0.29 & 0.43 & 0.54 & -0.25 & - & - & & - \\
EW-AC & 0.57 & 0.72 & -0.29 & 0.43 & 0.54 & -0.25 & 0.53 & -0.58 & & - \\
LW-AC & 0.39 & 0.38 & -0.54 & 0.34 & $0.79^{*}$ & 0.27 & - & & $-0.79^{*}$ & 0.45 \\
TR-EC & 0.46 & $0.83^{*}$ & -0.39 & 0.50 & 0.36 & -0.18 & - & - & & - \\
EW-EC & 0.54 & 0.74 & -0.32 & 0.34 & 0.43 & -0.27 & 0.42 & -0.70 & & - \\
LW_EC & 0.29 & 0.72 & -0.71 & $0.79^{*}$ & 0.54 & 0.40 & - & & $-0.82^{*}$ & 0.68 \\
\hline
\end{tabular}

${ }^{*} p<0.05$. 
$\mathrm{CO}_{2}$, which is in agreement with previous studies (Yazaki et al., 2001; Temperton et al., 2003; Norby \& Zak, 2011). Conversely, several researchers reported that elevated $\mathrm{CO}_{2}$ enhances growth and biomass (LaMarche et al., 1984; Crookshanks et al., 1998; Jarvis, 1998; Jach \& Ceulemans, 1999; Kilpeläinen et al., 2005, 2007; Pokorný et al., 2013; Bader et al., 2013; Klein et al., 2016), especially when nutrient supply is high (Nicolussi et al., 1995; Brown \& Higginbotham, 1986; Atwell et al., 2002; Yazaki et al., 2005; Drake et al., 2011). The response of young Norway spruce to elevated $\left[\mathrm{CO}_{2}\right]$ was negative and reduced annual ring, early- and latewood ( $p$ $<0.05)$ width. Also, Pokorný et al. (2012a) and Hättenschwiler et al. (1996) reported that elevated $\left[\mathrm{CO}_{2}\right]$ had no significant effect on Norway spruce growth, but in some species such as Scots pine elevated $\left[\mathrm{CO}_{2}\right]$ increased ring width, significantly (Kilpeläinen et al., 2005, 2007). The most negative impact of elevated $\left[\mathrm{CO}_{2}\right]$ was on latewood, this result conflicts with the findings of Hättenschwiler et al. (1996) who found positive significant effect on latewood. Furthermore, decreasing latewood width has caused an increase in early to latewood proportion in EC, however, it was not significant. Also, Kilpeläinen et al. (2005) found same result in Scots pine for early to latewood proportion. No evidence could be provided for the underlying cause of the reduced growth under elevated $\left[\mathrm{CO}_{2}\right]$. The effect of elevated $\mathrm{CO}_{2}$ on plants has been the topic of several thousand scientific articles with differing results (Körner, 2006). Some constrains in $\mathrm{CO}_{2}$ enrichment experiments which can be the main factors to conflict results were tree species, duration of experiment, concentration of fumigated $\mathrm{CO}_{2}$, drought stress, soil conditions, $\mathrm{CO}_{2}$ enrichment technology (Körner, 2006), and wood properties (Kilpeläinen et al., 2005). We presume that high concentration of fumigated $\mathrm{CO}_{2}$ (700 ppm) decreased spruce latewood formation in Beskedy Mts. by down-regulation of photosynthesis.

Climatic factors influencing juvenile Norway spruce radial increments in AC were generally similar to EC, although, a difference has observed between $\mathrm{AC}$ and EC. However, in EC temperature exerted a stronger influence than precipitation as indicated by the statistically significant correlation between temperature and radial growth (Table 3). This finding was further corroborated by the correlation coefficient between temperature in second half of growing season and latewood formation. As atmospheric $\mathrm{CO}_{2}$ levels have risen, plants have responded by decreasing stomatal conductance which can be reason to reducing water loss in transpiration and the resultant water saving in the ground and/or increase water-use efficiency (Egli et al., 1998; Runion et al., 1999; Körner, 2006; Bader et al., 2013). But in AC, the main factor significantly affecting radial growth was precipitation. Also, the correlation coefficient between radial increment and precipitation in May, the growing season and first half of the growing season has shown that precipitation has more influence in AC (Table 3). In Eastern Romania and in the Bavarian Forest (Germany) climatic responses were evaluated according to elevation (Wilson \& Hopfmueller, 2001; Sidor et al., 2015). At high elevation ( $\geq 1300$ or $\geq 1070 \mathrm{~m}$ a.s.l.), June-July temperature had positive influence but warm temperatures in this period reduced tree-ring width in low elevation. Beskedy Mts. elevation is $908 \mathrm{~m}$ a.s.l. and Norway spruce radial growth responds to temperature in the first half of the growing the season was consistent with Sidor et al. (2015) and Wilson \& Hopfmueller (2001) (at low elevation). Also, they reported that in low elevation tree-ring width was mainly controlled by summer precipitation but in our case study it was controlled by spring precipitation while summer precipitation had negative effects. In contrast to our observation Ulbrichová et al. (2015) reported that longitude, latitude and altitude significantly affected on spruce growth, and average annual temperature and average annual precipitation were not significant. 


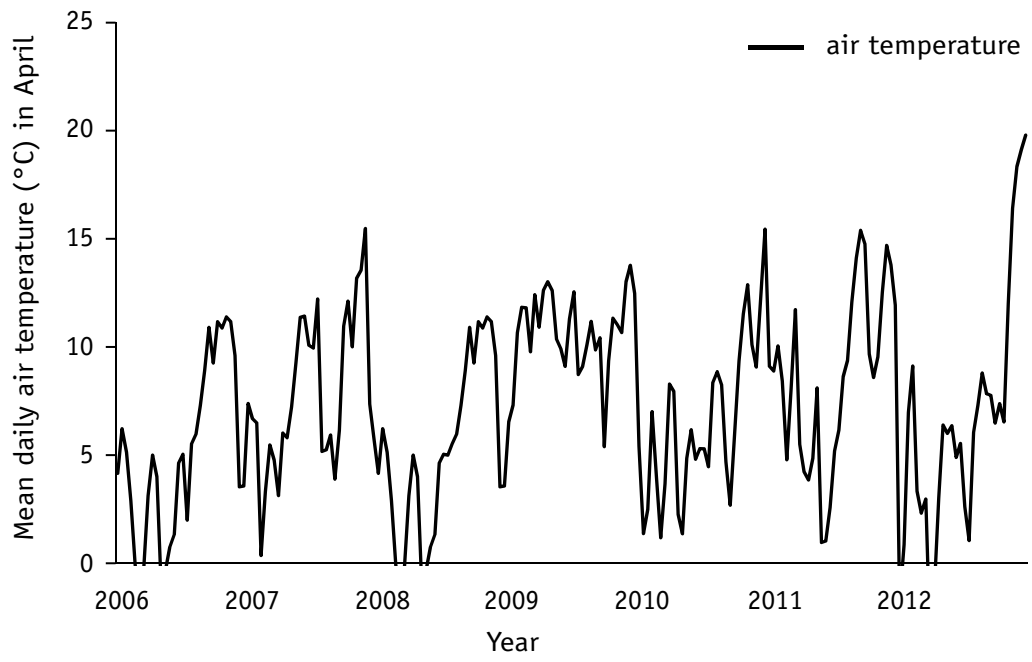

Figure 4. Mean air temperature $\left({ }^{\circ} \mathrm{C}\right)$ in April at the experimental site during 2006-2012.

Overall, the highest tree-ring widths were observed during 2009 and 2010, irrespective of $\mathrm{CO}_{2}$ treatment. In both years, the main reason for wider tree-rings was accelerated growth in earlywood. Enhancement during 2009 was attributed to April temperature, the month with the lowest frequency of air temperature and the highest-minimum daily air temperature (Figure 4). Therefore, it seems to be reasonable that cambial activity started earlier to earlywood cell formation (i.e. growing season started early in the Beskydy Mts. and produced wider ring during this year). Moreover, we found strong correlation coefficients between April temperature and radial increments. During 2010, the highest radial growth (chiefly earlywood) was probably due to Norway spruce reactions to precipitation in May or/and first half of growing season.

Earlywood growth trends during the past 100 years were closely associated with changing May rainfall patterns (Wimmer et al., 2000). In the Beskydy Mts. Norway spruce earlywood formation was more sensitive to precipitation, and responded negatively to high temperature in growing season and first half growing season. As- sociation among precipitation in May and earlywood formation was stronger than precipitation in the first half of the growing season, annual precipitation and growing season precipitation. Similar responses have also been found for other European regions, where Norway spruce radial growth affected by higher precipitation during spring months (Selås et al., 2002; Pokorný et al., 2012b; Zubizarreta-Gerendiain et al., 2012; Shishkova \& Panayotov, 2013; Rohner et al., 2016; Helama et al., 2016; found it for P. nigra), and Wimmer \& Grabner (1997) found negative effect precipitation from June to August in eastern Germany. Moreover, we find out that lower temperature during the first half growing season was favourable factor for Norway spruce radial growth, which was confirmed by Rohner et al. (2016) and Bijak (2009). Also we found that Norway spruce during spring months is sensitive to precipitation and warm temperature. It seems consistent with the results of Lebourgeois (2000), who confirmed that warm May temperature could reduce earlywood width by creating (mild) drought stress condition at the beginning of the growing season. 
Proportion of latewood increased with low precipitation in growing season (Kennedy, 1961). In the Beskydy Mts. precipitation was limited factor for Norway spruce latewood processes. We found significant negative correlation between precipitation in second half growing season and latewood formation. In Switzerland, also it was correlated by low precipitation between July-September (Rohner et al., 2016), also, at dry Mediterranean area in Portugal high precipitation in August decreased latewood formation in $P$. pinea (Campelo et al., 2006). Temperature was the main factor governed Norway spruce latewood increment in our research, also, literature from Mountains regions in Czech Republic confirmed that cold summers are the cause of small radial increments (Sander et al., 1995) and elevated air temperature during summer time stimulates latewood growth in Norway spruce (Pokorný et al., 2012b). In contrast, in southeastern Finland, Norway spruce ring width was affected by temperature of July and total precipitation of August (ZubizarretaGerendiain et al., 2012), and at tree line in Canada, Yamaguchi et al. (1993) found that late spring and entire growing season temperature influence on latewood formation.

\section{Conclusions}

Our finding of reduced stem radial growth under elevated $\mathrm{CO}_{2}$ implies that Norway spruce trees will sequester less carbon in stem wood under future atmospheric $\mathrm{CO}_{2}$ concentrations. We propose that Norway spruce can be acclimated to climate changes positively (especially) when spring starts early, as well as, it can be show negative acclimate under high level of $\mathrm{CO}_{2}$ concentration (700 ppm). Among the environmental factors, precipitation and temperature had a much stronger effect on tree-ring increment in Norway spruce in mountain regions, compared to $\left[\mathrm{CO}_{2}\right]$. In other words, probably in the future, Norway spruce may grow more vigorously in European moun- tain regions where future climate scenarios predict warmer spring temperatures coupled with increased precipitation early in the growing season.

Acknowledgements. This publication is an output of the CzechGlobe Centre that is being developed within the OP RDI and co-financed from EU funds and the State Budget of the Czech Republic (Project: CzechGlobe, Reg. No. CZ.1.05/1.1.00/02.0073). The authors are grateful for the financial support also by grant under COST EumixFor no. COST CZ LD 14063" Effect of mixture on stand tree species composition, structure and biomass".

\section{References}

Agrawal, S.B., Agrawal, M. (eds.) 1999. Environmental pollution and plant responses. CRC Press/Lewis Publishers, Boca Raton, Florida. 390 pp.

Atwell, B.J., Henery, M.L., Whitehead, D. 2002. Sapwood development in Pinus radiata trees grown for three years at ambient and elevated carbon dioxide partial pressures. - Tree Physiology, 23, 13-21.

Augustin, L., Barbante, C., Barnes, R.F., Barnola, J.M., Bigler, M., Castellano, E., Cattani, O., Chappallaz, J., Dahl-Jensen, D., Delmonte, B., Dreyfus, G., Durand, G., Falourd, S., Fischer, H., Flückiger,J., Hansson, M.E., Huybrechts, P., Jugie, G., Johnsen, S.J., Jouzel, J., Kaufmann, P., Kipfstuhl, J., Lambert, F., Lipenkov, V.Y., Littot, G.C., Longinelli, A., Lorrain, R., Maggi, V., Masson-Delmotte, V., Miller, H., Mulvaney, R., Oerlemans, J., Oerter, H., Orombelli, G., Parrenin, F., Peel, D.A., Petit, J-.R., Raynaud, D., Ritz, C., Ruth, U., Schwander, J., Siegenthaler, U., Souchez, R., Stauffer, B., Steffensen, J.P., Stenni, B., Stocker, T.F., Tabacco, I.E., Udisti, R., van de Wal, R.S.W., van den Broeke, M., Weiss, J., Wilhelms, F., Winther, J-.G., Wolff, E.W., Zucchelli, M. 2004. Eight glacial cycles from an Antarctic ice core. - Nature, 429(6992), 623-628.

Bader, M.K.F., Leuzinger, S., Keel, S.G., Siegwolf, R.T.W., Hagedorn, F., Schleppi, P., Körner, C. 2013. Central European hardwood trees in a high $\mathrm{CO}_{2}$ future: synthesis of an 8-year forest canopy $\mathrm{CO}_{2}$ enrichment project. - Journal of Ecology, 101, 1509-1519.

Bijak, S. 2009. Climate-growth relationships of Norway spruce in north-eastern Poland. - Levanic, T., Gricar, J., Hafner, P., Krajnc, R., Jagodic, S., Gärtner, H., Heinrich, I., Helle, G. (eds.). Trace - Tree Rings in Archaeology, Climatology and Ecology, Vol. 8. Proceedings of the Dendrosymposium 2009, April 
16th-19th 2009, Otočec, Slovenia. GFZ Potsdam, Scientific Technical Report STR 10/05, Potsdam, 98-103.

Brown, K., Higginbotham, K.O. 1986. Effects of carbon dioxide enrichment and nitrogen supply on growth of boreal tree seedlings. - Tree Physiology, 2, 223-232.

Buentgen, U., Frank, D.C., Nievergelt, D., Esper, J. 2006. Summer temperature variations in the Swiss Federal Research Institute WSL, Birmensdorf, Switzerland. - Journal of Climate, 19, 5606-5623.

Campelo, F., Nabais, C., Freitas, H., Gutiérrez, E. 2006. Climatic significance of tree-ring width and intraannual density fluctuations in Pinus pinea from a dry Mediterranean area in Portugal. - Annals of Forest Science, 64(2), 229-238.

Crookshanks, M., Taylor, G., Broadmeadow, M. 1998. Elevated $\mathrm{CO}_{2}$ and tree root growth: contrasting responses in Fraxinus excelsior, Quercus petraea and Pinus sylvestris. - New Phytologist, 138, 241-250.

Drake, J.E., Gallet, B.A., Hofmockel, K.S., Bernhardt, E.S., Billing, S.A., Jackson, R.B., Johnsen, K.S., Lichter, J., McCarthy, H.R., McCormack, M.L. 2011. Increases in the flux of carbon belowground stimulated nitrogen uptake and sustain the long-term enhancement of forest productivity under elevated $\mathrm{CO}_{2}$. - Ecology Letters, 14, 349-357.

Egli, P., Körner, C. 1997. Growth responses to elevated $\mathrm{CO}_{2}$ and soil quality in beech-spruce model ecosystems. - Acta Oecologica, 18(13), 343-349.

Egli, P., Maurer, S., Guentharot-Goerg, M.S., Körner, C. 1998. Effect of elevated $\mathrm{CO}_{2}$ and soil quality on leaf gas exchange and aboveground growth in beechspruce model. - New Phytologist, 140(2), 185-196.

Feliksik, A., Wilczynski, S. 2009.The effect of climate on tree-ring chronologies of native and nonnative tree species growing under homogenous site conditions. - Geochronometria, 33, 49-57.

Hättenschwiler, S., Schweingruber, F.H., Körner, C. 1996.Tree ring responses to elevated $\mathrm{CO}_{2}$ and increased $\mathrm{N}$ deposition in Picea abies. - Plant Cell and Environment, 19, 1369-1378.

Hauke, J., Kossowski, T. 2011. Comparison of values of Pearson and Spearman's correlation coefficients on the same sets of data. - Quaestiones Geographicae, 30(2), 87-93.

Helama, S., Läänelaid, A., Bijak, S., Jaagus, J. 2016. Contrasting tree-ring growth response of Picea abies to climate variability in western and eastern Estonia. - Geografiska Annaler Series A-Physical Geography, 98(2), 155-167.

IPCC. 2013. Summary for Policymakers. - Stocker, T.F., Qin, D., Plattner, G.-K., Tignor, M., Allen, S.K., Boschung, J., Nauels, A., Xia, Y., Bex, V., Midgley, P.M. (eds.). Climate Change 2013: The Physical Science Basis. Contribution of Working Group I to the Fifth Assessment Report of the Intergovernmental Panel on Climate Change. Cambridge University Press, Cambridge, United Kingdom and New York, NY, USA. 28 pp.
Jach, M.E., Ceulemans, R. 1999. Effects of elevated atmospheric $\mathrm{CO}_{2}$ on phenology, growth and crown structure of Scots pine (Pinus sylvestris) seedlings after two years of exposure in the field. - Tree Physiology, 19, 289-300.

Jarvis, P.G. 1998. European forests and global change. Cambridge University Press, Cambridge. 379 pp.

Kennedy, R.W. 1961. Variation and periodicity of summer wood in some second growth Douglas fir. Tappi, 44, 161-166.

Kilpeläinen, A., Gerendiain, A.Z., Luostarinen, K., Peltola, H., Kellomäki, S. 2007. Elevated temperature and $\mathrm{CO}_{2}$ concentration effects on xylem anatomy of Scots pine. - Tree Physiology, 27(9), 1329-38.

Kilpeläinen, A., Peltola, H., Ryyppoe, A., Kellomäki, S. 2005. Scots pine responses to elevated temperature and carbon dioxide concentration: growth and wood properties. - Tree Physiology, 5, 75-83.

Klein, T., Bader, M.K.F., Leuzinger, S., Mildner, M., Schleppi, P., Siegwolf, R.T.W., Körner, C. 2016. Growth and carbon relations of mature Picea abies trees under five years of free air $\mathrm{CO}_{2}$ enrichment. - Journal of Ecology, 104(6), 1720-1733.

Körner, C. 2006. Plant $\mathrm{CO}_{2}$ responses: an issue of definition, time and resource supply. - New Phytologist, 172(3), 393-411.

LaMarche, V.C., Graybill, D.A., Fritts, H.C., Rose, M.R.1984. Increasing atmospheric carbon dioxide: tree ring evidence for growth enhancement in natural vegetation. - Science, 225, 1019-1021.

Lebourgeois, F. 2000. Climatic signals in earlywood, latewood and total ring width of Corsican pine from western France. - Annals of Forest Science, 57, 155-164.

Madhu, M., Hatfield, J.L. 2013. Dynamics of plant root growth under increased atmospheric carbon dioxide. - Agronomy Journal, 105, 657-669.

Makino, A., Mae, T. 1999. Photosynthesis and plant growth at elevated levels of $\mathrm{CO}_{2}$. - Plant Cell Physiology, 40(10), 999-1006.

Mustafa, Y.T. 2012. Improving forest growth estimation Bayesian Networks for integrating satellite images and process-based forest growth models. Ph.D Thesis, Twente University of Netherland. 163 pp.

Nicolussi, K., Bortenschlager, S., Körner, C. 1995. Increase in tree-ring widthin subalpine Pinus cembra from the central Alps that may be $\mathrm{CO}_{2}$-related. Trees, 9, 181-189.

Norby, R.J., Zak, D.R. 2011. Ecological Lessons From Free-Air $\mathrm{CO}_{2}$ Enrichment (FACE) Experiments. The Annual Review of Ecology, Evolution, and Systematics, 42, 181-203.

Pearson, P.N., Palmer, M.R. 2000. Atmospheric carbon dioxide concentrations over the past 60 million years. - Nature, 406, 695-699.

Petit, J.R., Jouzel, J., Raynaud, D., Barkov, N.I., Barnola, J.-M., Basile, I., Bender, M., Chappellaz, J., Davis, M., Delaygue, G., Delmotte, M., Kotlyakov, V.M., Legrand, M., Lipenkov, V.Y., Lorius, C., Pepin, L., Ritz, C., Saltzman, E., Stievenard, M. 1999. Climate 
and atmospheric history of the past 420,000 years from the Vostok ice core, Antarctica. - Nature, 399(6735), 429-436.

Pokorný, R., Rajsnerová, P., Kubásek, J., Marková, I., Tomášková, I. 2012b. Effect of early to latewood proportion on Norway spruce biomass. - Acta Universitatis Agriculturae et Silviculturae Mendelianae Brunensis LX, 37(6), 287-292.

Pokorný, R., Tomášková, I., Marek, M.V. 2013. Response of Norway spruce root system to elevated atmospheric $\mathrm{CO}_{2}$ concentration. - Acta Physiologiae Plantarum, 35, 1807-1816.

Pokorný, R., Tomášková, I., Slípková, R. 2012a. The effect of air elevated $\left[\mathrm{CO}_{2}\right]$ on crown architecture and aboveground biomass in Norway spruce $(\mathrm{Pi}$ cea abies (L.) Karst). - Baltic Forestry, 18(1), 2-11.

Rohner, B., Weber, P., Thürig, E. 2016. Bridging tree rings and forest inventories: How climate effects on spruce and beech growth aggregate over time. - Forest Ecology and Management, 360, 159-169.

Runion, G.B., Entry, J.A., Prior, S.A., Mitchen, R.Y., Rogers, H.H. 1999. Tissue chemistry and carbon allocation in seedling of Pinus palustris subjected to elevated atmospheric $\mathrm{CO}_{2}$ and water stress. - Tree Physiology, 19, 329-335.

Sander, C., Eckstein, D., Kyncl, J., Dobry, J. 1995. The growth of spruce (Picea abies (L.) Karst) in the Krkonoše (Giant) Mountains as indicated by ring width and wood density. - Annals of Forest Science, 52(5), 401-410.

Selås,V., Piovesan, G., Adams, J.M., Bernabei, M. 2002. Climatic factors controlling reproduction and growth of Norway spruce in southern Norway. Canadian Journal of Forest Research, 32, 217-225.

Shishkova, V., Panayotov, M. 2013. Pinus nigra Rrn. Tree ring chronology from Slavyanka Mts. in Bulgaria is strongly related to regional drought events. - Forestry Ideas, 19(45), 79-90.

Sidor, C.G., Popa, I., Vlad, R., Cherubini, P. 2015. Different tree-ring responses of Norway spruce to air temperature across an altitudinal gradient in the Eastern Carpathians (Romania). - Trees, 29, 985-997.

Smith, A.R., Lukace, M., Bambrick, M., Miglietta, F., Godbold, D.L. 2013. Tree species diversity interacts with elevated $\mathrm{CO}_{2}$ to induce a greater root system response. - Global Change Biology, 19, 217-228.

Temperton, V.M., Grayston, S.J., Jackson, G., Barton, C.V.M., Millard, P., Jarvis, P.G. 2003. Effects of elevated carbon dioxide concentration on growth and nitrogen fixation in Alnus glutinosa in a long-term field experiment. - Tree Physiology, 23, 1051-1059.

Ulbrichová, I., Podrázský, V., Beran, F., Zahradník, D., Fulín, M., Procházka, J., Kubeček, J. 2015. Picea abies provenance test in the Czech Republic after 36 years Central European provenances. - Journal of Forest Science, 6(11), 465-477.

Underwood, C.A. 2007. Century-scale trends in climatic variability for the Pacific Northwest from Western Juniper (Juniperus occidentalis Hook. ssp. occidentalis) tree-ring data. MScThesis, University of Tennessee, Knoxville. 211 pp.

Urban, O., Janouš, D., Pokorný, R., Marková, I., Pavelka, M., Fojtík, Z., Šprtová, M., Kalina, J., Marek, M.V. 2001. Glass domes with adjustable windows: A novel technique for exposing juvenile forest stands to elevated $\mathrm{CO}_{2}$ concentration. - Photosyntetica, 39, 395-401.

Wilson, R.J., Hopfmueller, M. 2001. Dendrochronological investigations of Norway spruce along an elevational transect in the Bavarian Forest. - Dendrochronologia, 19(1), 67-79

Wimmer, R, Strumia, G., Holawe, F. 2000. Use of false rings in Austrian pine to reconstruct early growing season precipitation. - Canadian Journal of Forest Research, 30, 1691-1697.

Wimmer, R., Grabner, M. 1997.Effects of climate on vertical resin duct density and radial growth of Norway spruce (Picea abies (L.) Karst.). - Trees, 11, 271-276.

Wolff, E., Fung, I., Hoskins, B., Mitchell, J., Palmer, T., Santer, B., Shepherd, J., Shine, K., Solomon, S., Trenberth, K., Walsh, J., Wuebbles, D. 2014. Climate Change: Evidence \& Causes. - An overview from the Royal Society and the US National Academy of Sciences. $36 \mathrm{pp}$.

Yamaguchi, D.K., Filion, L., Savage, M. 1993. Relationship of temperature and light ring formation at subarctic treeline and implication for climate reconstruction. - Quanternary Research, 39, 256-262.

Yazaki, K., Funada, R., Mori, S., Maruyama, Y., Abaimov, Y.K., Kayama, M., Koike, T. 2001. Growth and annual ring structure of Larix sibirica grown at different carbon dioxide concentrations and nutrient supply rates. - Tree Physiology, 21, 1223-1229.

Yazaki, K., Maruyama, Y., Mori, M., Koike, T., Funada, R. 2005. Effects of elevated carbon dioxide concentration on wood structure and formation in trees. - Omasa, K., Nouchi, I., De Kok, L.J. (eds.) Plant Responses to Air Pollution and Global Change. Springer, Tokyo, 89-97.

Zubizarreta-Gerendiain, A., Gort-Oromi, J., Mehtätalo, L., Peltola, H., Venäläinen, A., Pulkkinen, P. 2012. Effects of cambial age, clone and climatic factors on ring width and ring density in Norway spruce (Picea abies) in southeastern Finland. - Forest Ecology and Management, 263, 9-16. 